\title{
越波低減型防波護岸の天端高さと作用波圧 \\ Crest height and wave pressure of a new type of shore protection \\ to reduce wave overtopping
}

\author{
片岡保人*、中岡威博*、中川知和**、浜崎義弘***、杉井謙一***、村上塸介****、入江功 \\ Yasuto Kataoka, Takehiro Nakaoka, Tomokazu Nakagawa, Yoshihiro Hamazaki, Kenichi Sugii, \\ Keisuke Murakami and Isao Irie
}

\begin{abstract}
A new type of shore protection, the shape of which is an overhanging inverse triangle, called the "nabla" type, is proposed to reduce crest height and wave overtopping amount. Crest heights and wave pressures when using this shore protection are investigated by experiments using a water channel. The crest heights of the nabla type are almost as low as that of the "flare" type, the shape of which is an overhanging circular arc, and about 2/3 lower than that of the conventional vertical shore protection. It is shown that the crest height mainly depends on the specific volume between the front of the shore protection and the water surface. It is thought that the nabla type is useful due to its simple shape in comparison with the flare type, although wave pressures when using the nabla type become a little larger than that of the flare type as the depth of water decreases and transfers to the wave breaking region.
\end{abstract}

Keywords: Shore protection, Crest height, Wave pressure, Overtopping

\section{1.はじめに}

空港や発電ブラントなどを、外洋に面した比較的大水深、高波浪の沿岸域に建設する際には、これらの施設を 確実に保全するために、護岸での越波量を極力低減することが要求される。従来の直立型護岸の場合、護岸の天 端高さを高くすることで、越波量を低蔵しているため、設計波高が大きくなるにしたがって護岸断面は巨大化す る恐れがある。さらに、臨海公園用の親水性護岸や、航空機の離着陸のため高さ制限を考虑する必要がある空港 用護岸などでは、非越波と低天端の相反する課題を両立させることが強く望まれている。この課題を解決する護 岸のひとつとして、表 1 中に示すような護岸前面が沖側に張り出した円弧形状のフレア型護岸が提案され 1)、越 波量がゼロとなるために必要な最小の護岸天端高さ（以下、限界天端高さという）が従来の直立消波護岸に比へ て苏めて低く、沖波波高以下となることが明らかにされている。

本研究では、製作性、施工性を加味し、フレア型護岸の前面形状をより簡素化した逆三角形型護岸（表 1 参照 以下ナブラ型護岸という）を新たに提案し、これら護岸の越波阻止性能およひ護岸に作用する波圧特性を明らか にすることを目的としている。

\section{2.実臨装置と㴬定条件}

\section{(1)限界天端高さの测定}

ナブラ型護岸の越波阻止性能を把握するために、また、フレア型護岸のそれとの比較を行うために、両護岸の 限界天端高さを水理実験により求めた。実験は、四 1 に示す 2 次元造波水槽（長さ $30 \mathrm{~m}$ 、高さ $1.2 \mathrm{~m}$ 、幅 $0.6 \mathrm{~m}$ ） の中に海底勾配を模擬した勾配 $1 / 20$ の不透過斜面を設置し、沖側水平床部の水深を $\mathrm{h}_{0}=85 \mathrm{~cm}$ として行った。実 験に用いたナブラ型およびフレア型護岸モデルの形状、寸法を表 1 に示す。護岸高さは全て $\mathrm{B}=36.2 \mathrm{~cm}$ とし、護 岸奥行き深さ $\mathrm{D}$ と護岸高さ $\mathrm{B}$ の比は $\mathrm{D} / \mathrm{B}=0.5 、 1$ の 2 種類とし、 $\mathrm{D} / \mathrm{B}=0.5$ のナブラ型護岸については護岸前面角

\footnotetext{
* (株)神戸製鋼所機械研究所構造強度研究室（テ651-2271 神戸市西区高塚台 1 丁目 5-5）

** 正会員 (株)神戸製鋼所機械研究所構造強度研究室

***正会員 (株)神戸製鋼所都市環境事業部構造技術部

**** 正会員 宮崎大学工学部土木環境工学科

***** 正会員 九州大学工学部建設都市工学科
} 
度を $\theta=45^{\circ} 、 63^{\circ}$ の 2 種類とし た。なお、フレア型 $\mathrm{D} / \mathrm{B}=1$ の形 状は半径 $36.2 \mathrm{~cm}$ の $1 / 4$ 円で、フ レア型 $\mathrm{D} / \mathrm{B}=0.5$ の形状は底面に 対して垂直な半径 $45.25 \mathrm{~cm}$ $(=1.25 \times 36.2 \mathrm{~cm})$ の円弧の一部 になっている。護岸の限界天端 高さ hc は、表 2 に示す護岸の設 置水深 h に対して入射させる規 則波の沖波波高 $\mathrm{H}_{0}$ を種々変えて 越波の有無を逐次確認しながら 求めた。越波有りとは、護岸法 線前緑より背後側に少しでも水 が浸入した場合とし、越波の有 無は、ビデオに録画した映像と 目視により判断した。波形勾配 は $\mathrm{H}_{0} / \mathrm{L}_{0}=0.036 、 0.012\left(\mathrm{H}_{0}:\right.$ 沖 波波高、 $\mathrm{L}_{0}$ : 沖波波長) の 2 種 類とし、護岸前面には消波工は 置かず、護岸単体での特性を調 べることとした。 (2)波圧分布の測定

波圧分布の測定は、限界天端 高さの測定と同様に、2 次元造 波水槽の中に勾配 1/20 の不透過 斜面を設置し、沖側水平床部の 水深を $\mathrm{h}_{0}=85 \mathrm{~cm}$ として行った。 実験に用いた護岸は、後に述べ る越波阻止性能がほほ同等のナ ブラ型 I、III と、フレア型IVの 3 種類とし、護岸の前面には消 波工を置かずに、護岸単体での 波圧分布を測定した。入射波の 波形勾配は $\mathrm{H}_{0} / \mathrm{L}_{0}=0.036$ とし、 表 3 に示す設置水深 $\mathrm{h}$ と入射波 高 $\mathrm{H}_{0}$ の各組み合わせについて波 圧分布を測定した。測定には受 圧面直径が $8 \mathrm{~mm}$ の小型圧力計 を用い、圧力計 8 個を、図 1 に 示すように護岸前面の中心線上 に沿ってほほ等間隔になるよう に埋め込み、出力信号をサンプ リング周波数 $1 \mathrm{kHz}$ でデジタル 収録した。測定時間は 8 秒間で、 $4 \sim 6$ 波計測し、各波形の最大波 圧値の平均値を作用波圧値とし た。
表 1 護岸モデルの形状と寸法

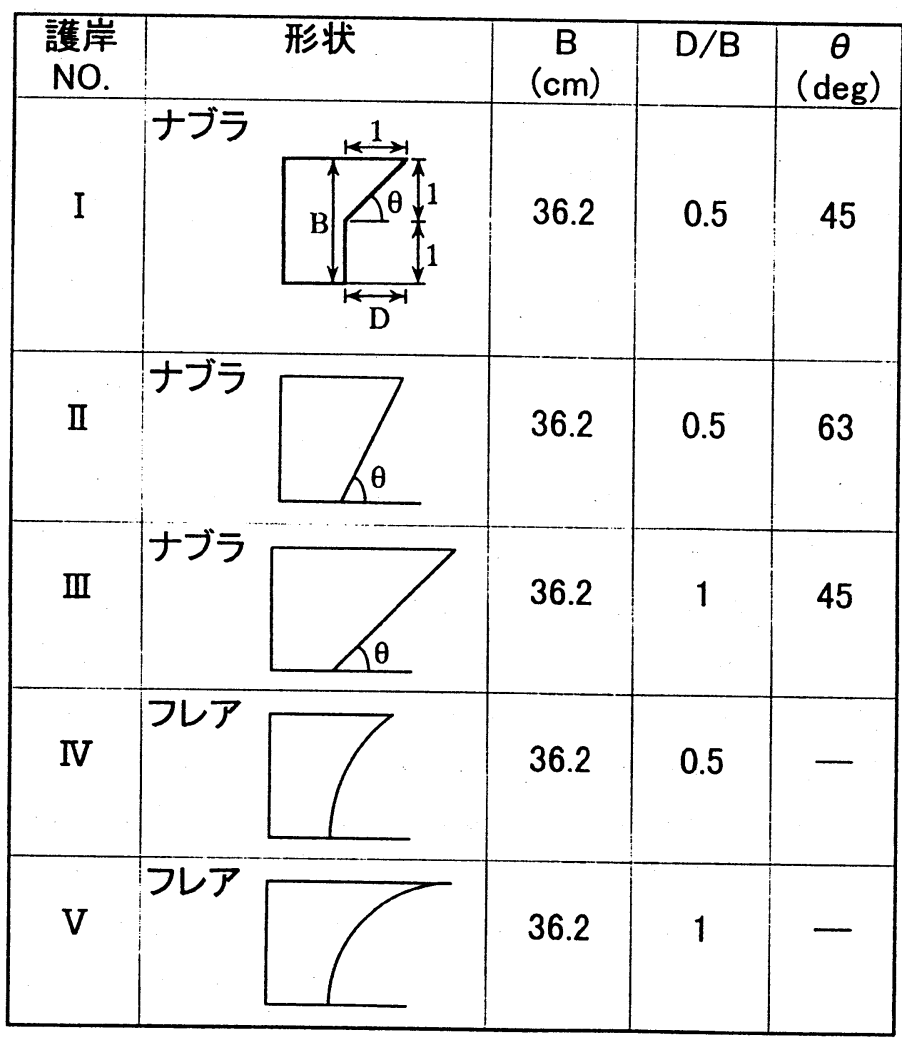

表 2 限界天端高さの測定に関する実験条件

\begin{tabular}{|c|c|c|}
\hline 護岸 NO. & $\mathrm{H}_{0} / \mathrm{L}_{0}$ & $\mathrm{~h}(\mathrm{~cm})$ \\
\hline \multirow[t]{2}{*}{ I } & 0.036 & $22.5, \quad 24, \quad 25.5, \quad 27, \quad 28.5$ \\
\hline & 0.012 & $21, \quad 22.5, \quad 24, \quad 25.5, \quad 27$ \\
\hline \multirow[t]{2}{*}{ II } & 0.036 & $22.5, \quad 24, \quad 25.5, \quad 27, \quad 28.5$ \\
\hline & 0.012 & $\begin{array}{lllll}21, & 22.5, \quad 24, & 25.5, & 27 \\
\end{array}$ \\
\hline \multirow[t]{2}{*}{ III } & 0.036 & $22.5, \quad 24, \quad 25.5, \quad 27, \quad 28.5, \quad 30$ \\
\hline & 0.012 & $21, \quad 22.5, \quad 24, \quad 25.5, \quad 27$ \\
\hline \multirow[t]{2}{*}{ IV } & 0.036 & $22.5, \quad 24, \quad 27, \quad 30$ \\
\hline & 0.012 & $21, \quad 22.5, \quad 24, \quad 25.5, \quad 27$ \\
\hline \multirow[t]{2}{*}{ V } & 0.036 & $27, \quad 30, \quad 31.5$ \\
\hline & 0.012 & $24, \quad 25.5, \quad 27, \quad 28.5$ \\
\hline
\end{tabular}

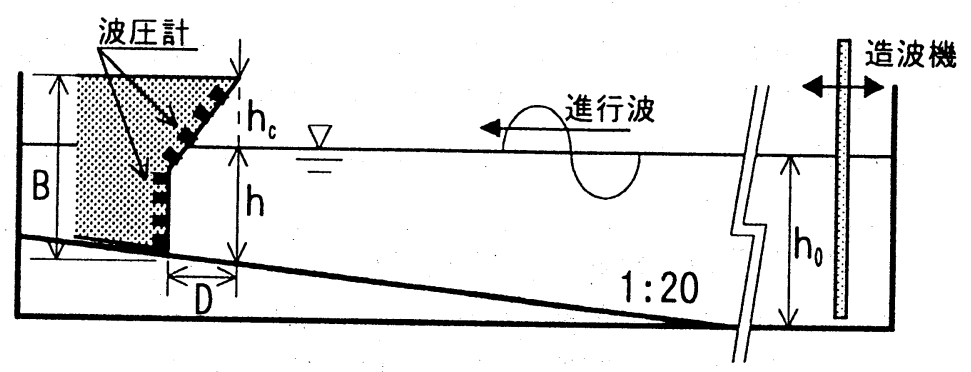

図 1 ，実験水槽の概要 
表 3 波圧分布の測定に関する実験条件

\begin{tabular}{|c|c|c|c|}
\hline $\mathrm{B}(\mathrm{cm})$ & $\mathrm{D} / \mathrm{B}$ & $\mathrm{h}(\mathrm{cm})$ & $\mathrm{H}_{0}(\mathrm{~cm})$ \\
\hline \multirow{3}{*}{36.2} & \multirow{3}{*}{0.5} & 27 & $11,13,15$ \\
\cline { 3 - 4 } & & 24 & $11,13,15$ \\
\cline { 3 - 4 } & & 21 & $11,13,15$ \\
\hline
\end{tabular}

\section{3.実鮽結果と考察}

(1) 限界天端高さ

図 2 (a)(b)はそれぞれ、入射波の 波形勾配 $\mathrm{H}_{0} / L_{0}$ が 0.036 と 0.012 の場合について、相対設置水深 $\mathrm{h} / \mathrm{H}_{0}$ に対する、沖波波高で無次元 化した限界天端高さ hc/Ho(以下、 相対限界天端高さという) を示し たものである。図中の○、、、ロ、

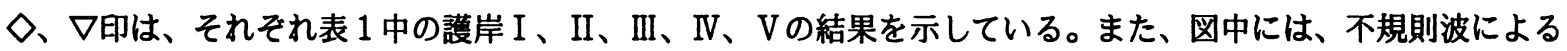
実験であり必ずしも直接対応はしないが、十印で直立消波護岸の越波量算定図 2)から読みとった相対天端高さも 図示している。ただし、海底勾配が 1/20に対する越波量算定図が無いことと、越波量がゼロとなる護岸天端高さ は図から読みとることはできないので、便宜的に沖波波高 $\mathrm{H}_{0}=2 \mathrm{~m}$ 、越波流量 $\mathrm{q}=2 \times 10^{-4}\left(\mathrm{~m}^{3} / \mathrm{m} \cdot \mathrm{sec}\right)$ とし、海底 勾配が $1 / 10$ と $1 / 30$ の場合の相対天端高さの平均値で示している。

図 2 より、ナブラ型護岸はフレア型とともに、直立消波護岸に比べて非常に越波が生じにくい形状であることが わかる。これら護岸は、直立護岸の $2 / 3$ 以下、形状、波浪条件によっては $1 / 2$ 以下の天端高さで越波量ゼ口を実現 可能であると考えられる。また、今回実験した範囲で、ナブラ型およびフレア型護岸の越波阻止性能を比較する と、護岸 $\mathrm{V}$ が最も相対限界天端高さ $\mathrm{hc} / \mathrm{H}_{0}$ が低く性能が良いことがわかり、護岸I I゙最も悪くなっている。そし て、護岸 I、III、Iは、これらの中間でほほ同等の性能を示している。これらの結果より、越波阻止性能は、単 に護岸奥行き深さ $\mathrm{D}$ と護岸高さ $\mathrm{B}$ の比 $\mathrm{D} / \mathrm{B}$ に依存するのではなく、図 3 に示す、護岸下面の静水面上の体積（静 水面上の護岸のふところの体積） S に大きく依存するものと考えられる。図 3に示すように、同じ水深において、 護岸 V の護岸下面の静水面上の体積（ $\mathrm{S}_{\mathrm{v}}$ ）が最も大きく、護岸IIのそれ（ $\mathrm{S}_{\mathrm{II}}$ ）が最も小さく、護岸 I、III、IN の場合は、それらの中間でほほ同じ大きさになっている。すなわち、

$$
\mathrm{S}_{\mathrm{v}}>\mathrm{S}_{\mathrm{I}} \doteqdot \mathrm{S}_{\text {II }} \doteqdot \mathrm{S}_{\mathrm{V}}>\mathrm{S}_{\text {II }}
$$

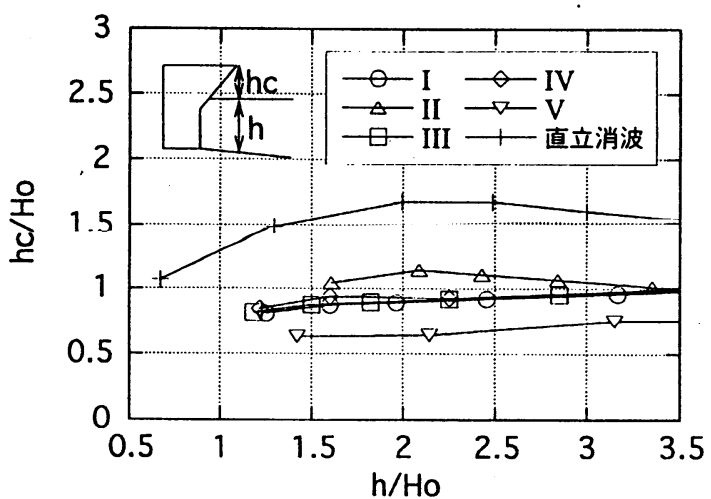

(a) $\mathrm{Ho} / \mathrm{LO}=0.036$

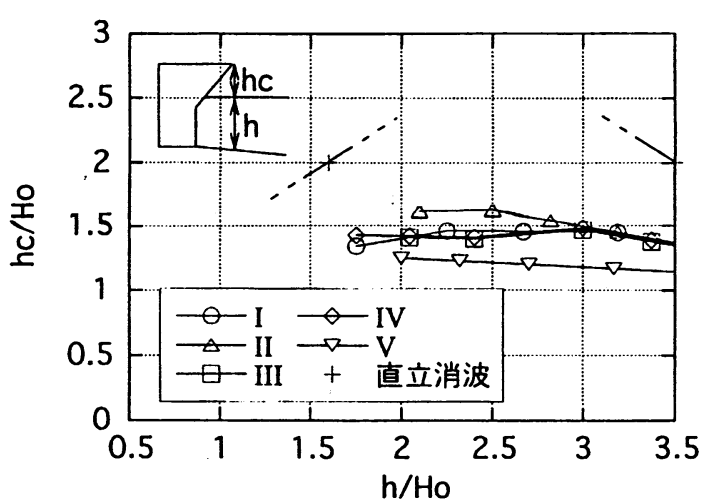

(b) $\mathrm{Ho} / \mathrm{Lo}=0.012$

図 2 相対設置水深に対する限界天端高さの変化

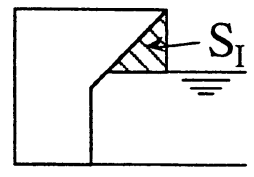

I

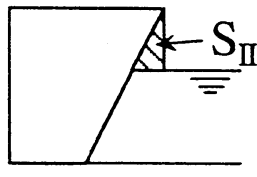

II

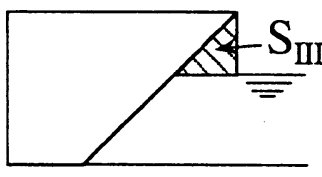

III

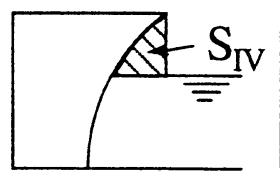

IV

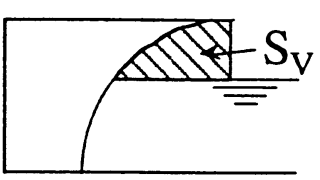

$\mathrm{V}$

図3 各護岸の護岸下面の静水面上の体積 
となっている。このことより、越波阻止性能は、護岸下面の静水面上の体積 S が同じであればほほ同等となり、 また S を大きくするほど向上するものと考えられる。

(2)護岸に作用する波圧特性

図4、5、6はそれぞれ、越波阻止性能がほほ同等の護岸 I、III、IV の波圧分布を示したもので、各図の(a)(b)(c) は護岸設置水樑を変化させている。図の縦軸は、静水面を原点とし鉛直上向きを正にとった座標で波圧計測位置 を表しており、護岸高さ B で無次元化している。横軸は、護岸面に対して法線方向の波圧を沖波波高相当の静水 圧で無次元化している。また、眓中には、護岸形状もあわせて示している。

図に示すように、波圧の分布形状は入射波高 $\mathrm{H}_{0}$ や護岸設置水深 h $\mathrm{h}$ により異なるが、最大波圧は、静水面上か ら護岸高さ B の約 10\%程度の間に生じており、その值は沖波波高相当の静水圧の 1〜2 倍程度になっている。

図 4〜6 の(a)図に示す水深が比較的深い場合には、波はまだ研波していないので、護岸形状に依らず、波圧分

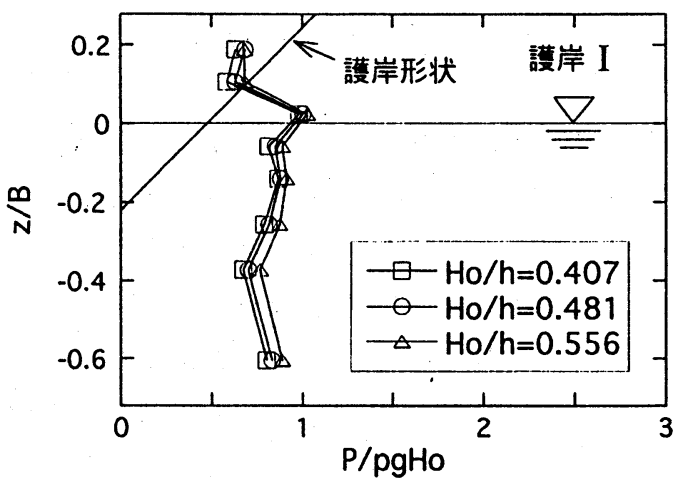

(a) $h / B=0.746$

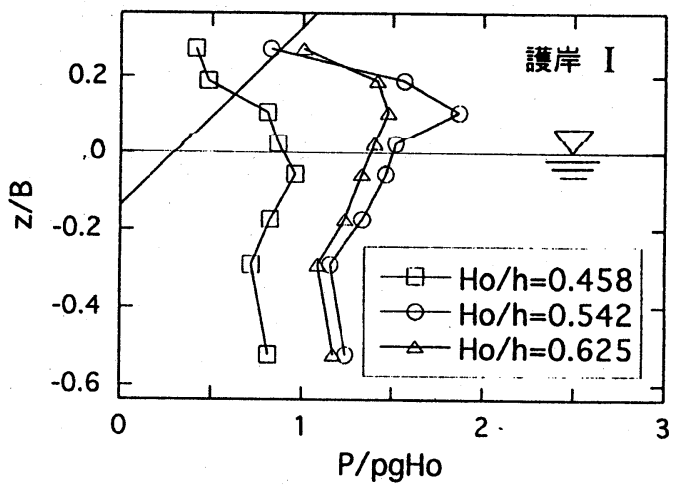

(b) $h / B=0.663$

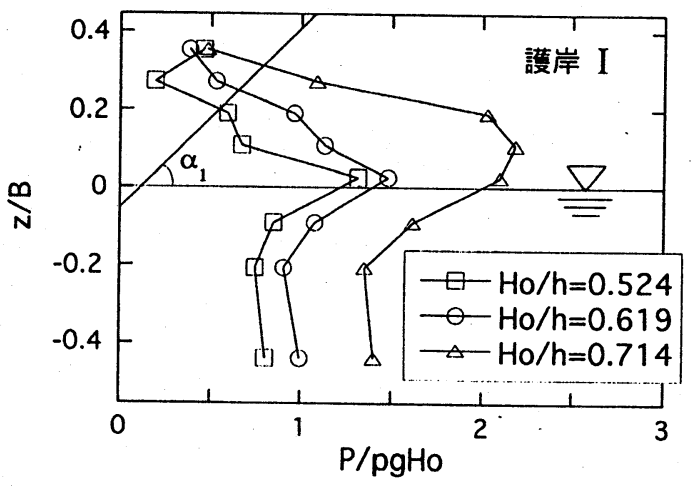

(c) $h / B=0.580$

図 4 護岸に作用する波圧分布（護岸 I ）

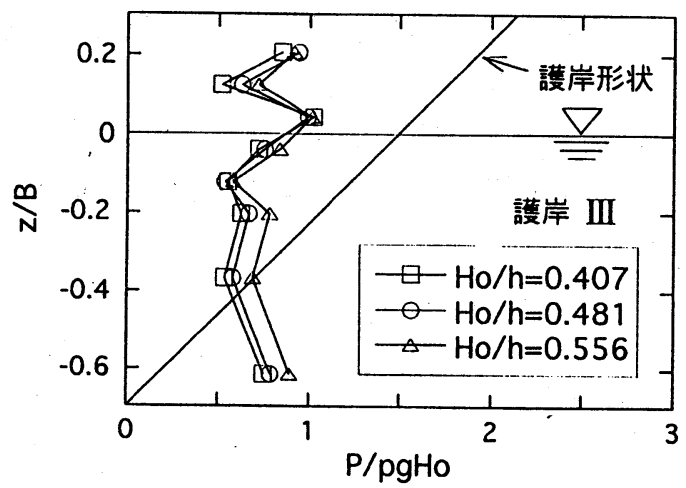

(a) $h / B=0.746$

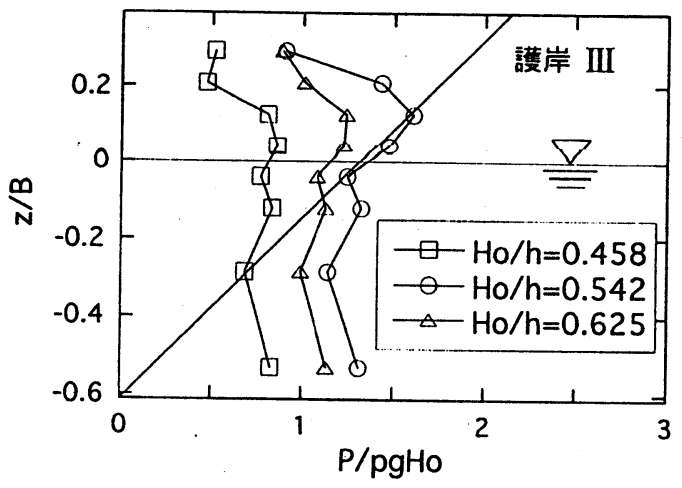

(b) $h / B=0.663$

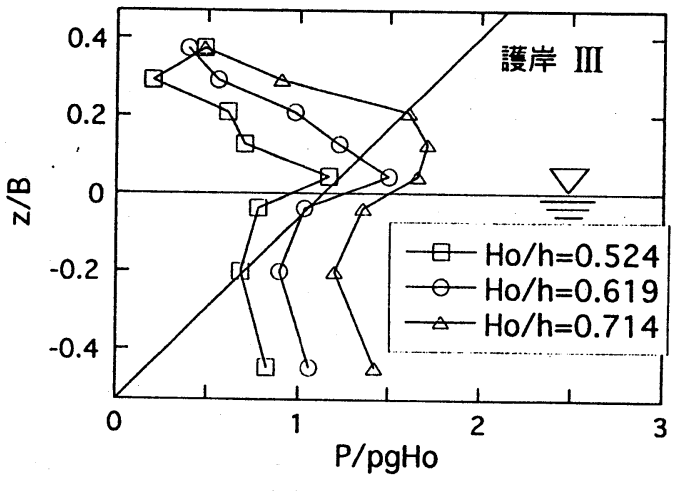

(c) $h / B=0.580$

図 5 護岸に作用する波圧分布（護岸III） 
布はほほ同じ形をしており、最大波圧値も沖波波高相当の静水圧程度になっている。これに対して、図 4 〜 6 (b)図から(c)図へと、水深が浅くなるにしたがって、波が砕波し始め、ナブラ型護岸における作用波圧がフレア型 のそれに比へて大きくなってくる。また、水深が浅く入射波高が大きいときにナブラ型護岸で最大波圧值を示し た部分の波形を観察すると、衝撃砕波圧の発生時に見られるような双峰型波形の前部が切り立った波形を呈して いた。ナブラ型讙岸における作用波圧がフレア型のそれに比へて大きくなる理由として、護岸前面と波面が成す 角度の違いが考えられる。直立讙岸に衛撃确波圧が生じる場合、その波圧值は、砕波により切り立った波面と直 立壁面との成す角度が小さいほど大きくなるといわれている 3)。今回実験した護岸形状と水深の笵囲では、水深 が浅くなると、ナブラ型護岸の前面と静水面が成す角度 $\alpha_{1}$ は、フレア型のそれ $\left(\alpha_{2}\right)$ よりも小さくなってくる （図 4(c)、6(c)参照）。このため、護岸前面と研波した波の波面が成す角度も水深が浅くなると、ナフラ型の 方がフレア型よりも小さくなり、波圧が大きくなったものと考えられる。

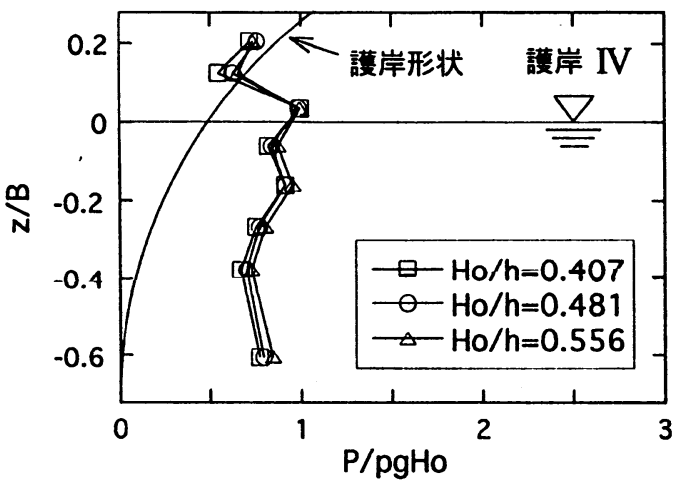

(a) $h / B=0.746$

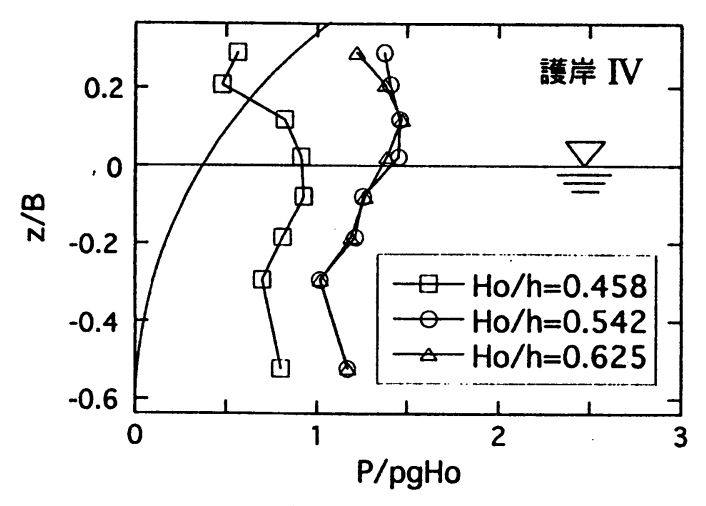

(b) $h / B=0.663$

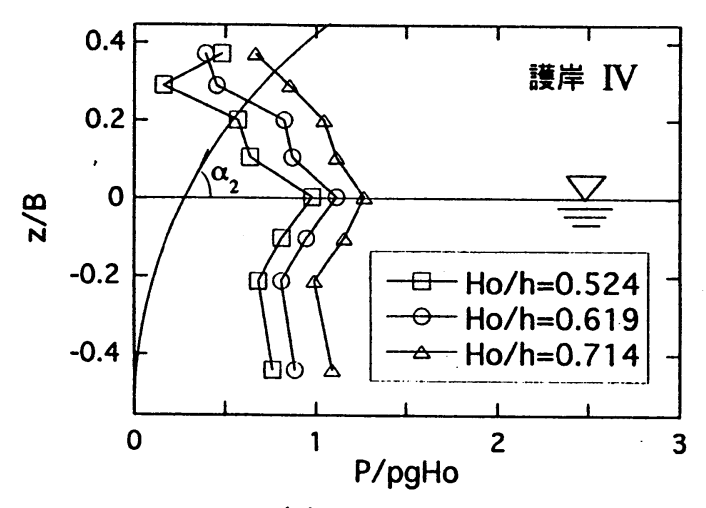

(c) $h / B=0.580$

また、図 4 (c)、図 5 (c)の $\mathrm{H} / \mathrm{h}=0.714$ の場合を 比較すると、ナブラ型讙岸 I の方が、IIIよりも波圧 が少し大きくなっている。本波高条件の場合、引き 波時の波面は $\mathrm{z} / \mathrm{B}=-0.2$ のあたりまで下がり、そこ から波面が上昇してくる。このとき、護岸IIIの場合 は、水流は斜め $45^{\circ}$ 上方向にのみ上昇していくのに 対して、I の場合は、護岸前面の屈曲部で水流の力 向が急に変えられ、その反力が護岸前面に作用する ことになる。この反力の作用が、ナブラ型亚よりも I の波圧が少し大きくなった原因のひとつと考えら れる。

\section{4.おわりに}

上に述べたように、本研究で提案したナブラ型謨 岸は、非越波、低天端護岸のひとつであるフレア型 護岸とほほ同等の越波阻止性能を示した。本護岸は、 水深が比較的浅い場合には、屈曲部で若干の波圧上 昇はあるものの、従来の直立型護岸に比べ天端高さ は 2/3 以下となり、かつ形状も比較的簡素なことか ら、実用上有益な蕟岸形式であると考えられる。

今後は、(1)屈曲部近傍の詳細な波圧特性把握と低 滅方法、(2構造設計を考える上での波力特性の検討、 (3)護岸の反射率の検討などをおこなっていく予定で ある。

\section{参考文献}

1）村上啓介-入江功 -上久保祐志 (1996) : 非越波 型防波蕟岸の護岸天端高さと作用波圧につい て，海岸工学論文集，第 43 巻，pp.776-780.

2）合田良美 (1990)：港湾構造物の耐波設計, 鹿島 出版会, pp.122-123.

3）合田良美 (1973):衙擊砕波圧を受ける混成防波 堤の挙動に関する考察，港湾技術研究所報告, 第 12 巻, 第 3 号, pp.3-29.

図6 護岸に作用する波圧分布（護岸IV） 